\title{
Familial insulin-resistant diabetes, multiple somatic anomalies, and pineal hyperplasia
}

\author{
R. J. WEST, J. K. LLOYD, and W. M. L. TURNER \\ From the Department of Child Health, Institute of Child Health, London, and the Paediatric \\ Department, Burnley General Hospital, Burnley
}

\begin{abstract}
West, R. J., Lloyd, J. K., and Turner, W. M. L. (1975). Archives of Disease in Childhood, 50, 703. Familial insulin-resistant diabetes, multiple somatic anomalies, and pineal hyperplasia. A syndrome comprising unusual facies, dry skin, acanthosis nigricans, thickened nails, hirsutism, dental precocity and dysplasia, abdominal protuberance, and phallic enlargement is described in 2 sibs. Both have developed diabetic ketoacidosis with insulin resistance. The elder child, a girl, had recurrent septic episodes and died at the age of 7.8 years. At necropsy the pineal gland was hyperplastic, weighing $900 \mathrm{mg}$. Investigation of the younger sib over a 4-year period has shown decreasing glucose tolerance, and he was frankly diabetic with ketoacidosis by the age of $6 \cdot 8$ years. Serum insulin concentrations have always been grossly raised. Though the mechanism for insulin resistance has not been definitely established, a functional abnormality of the hypothalamus or pituitary is postulated to explain the many endocrine features of the syndrome.
\end{abstract}

The role of the pineal gland in human metabolism is uncertain; a syndrome in which pineal hyperplasia appears to be an integral part may help to elucidate its function. Such a syndrome was reported by Rabson and Mendenhall (1956) who described 3 sibs who initially presented with dental and skin abnormalities, abdominal distension, and phallic enlargement. Insulin-resistant diabetes developed, and the patients died of ketoacidosis and intercurrent infection during childhood. At necropsy pineal hyperplasia was found in all 3 children. 5 other children described in published reports had similar features (Mason and Sly, 1937; Wiedermann et al., 1968; Barnes et al., 1974), but biochemical details are limited. This report records two further examples of the syndrome, and speculates on the role of the pineal gland in this disorder.

\section{Case reports}

Case 1. A girl, the first child of healthy unrelated parents, was born at term after an uneventful pregnancy, weighing $2 \mathrm{~kg}$. Unusual facies and abdominal distension were noted from birth. Primary dentition started at 3 months, and was complete by $1 \cdot 2$ years. Secondary dentition started at the age of 3.5 years and the teeth were clearly abnormal in appearance. Thickened

Received 20 January 1975. finger and toe nails were present from infancy. Developmental progress was normal.

Throughout childhood she had a good appetite but appeared more thirsty than other children. At the age of 5 , during a routine medical examination, she was found to have glycosuria with ketonuria, and was admitted to hospital. On admission height and weight were both well below the 3rd centile, but she did not appear acutely ill. She was noted to have unusual facies, hirsutism, dry skin with acanthosis nigricans of neck and axilla, thickened nails, dysplastic and carious teeth with greatly advanced dental age (Fig. 1), and a deeply fissured tongue. Her abdomen was markedly protuberant and the clitoris was large but there was no evident organomegaly or pubic or axillary hair.

Investigation showed a fasting blood sugar of 155 $\mathrm{mg} / 100 \mathrm{ml}$ and treatment of her diabetes mellitus was started with soluble insulin, the dose being gradually increased to 300 IU daily, without any improvement of ketonuria, polyuria, or lowering of blood sugar. Insulin antibodies could not be detected. The sequential addition of prednisone, chlorpropamide, and metformin to the insulin therapy did not favourably influence the hyperglycaemia, and accordingly all antidiabetic therapy was discontinued.

Over the next 2 years she remained hyperglycaemic and ketotic, and her general health gradually deteriorated. She lost weight, had several episodes of dental sepsis, and on one occasion ketoacidosis with semi-coma required treatment with intravenous fluids. 


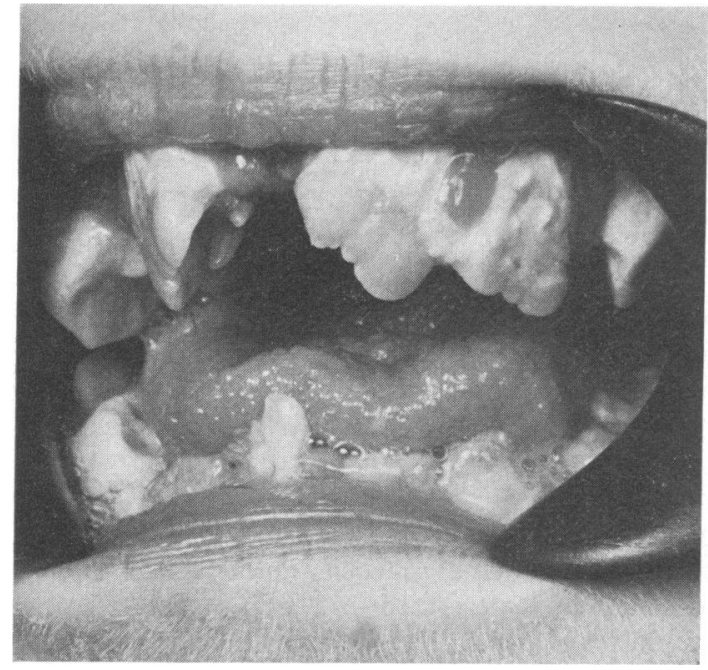

FIG. 1.-Case 1. Dysplastic and carious teeth at the age of 7 years.

At the age of 6.8 years she was admitted to The Hospital for Sick Children, London, for further study. On examination she weighed $11.5 \mathrm{~kg}$ and was grossly wasted, with no apparent subcutaneous fat. The somatic features were as already described and her dental age was assessed at around 12 years. Investigations showed $\mathrm{Hb} 14.5 \mathrm{~g} / 100 \mathrm{ml}$, WBC $12900 / \mathrm{mm}^{3}$ with $70 \%$ neutrophils. Serum sodium was $119 \mathrm{mEq} / 1$, potassium $2.7 \mathrm{mEq} / 1$, chloride $97 \mathrm{mEq} / 1$, bicarbonate $9 \mathrm{mmol} / 1$, and urea $26 \mathrm{mg} / 100 \mathrm{ml}$. Fasting blood glucose was $235 \mathrm{mg} / 100 \mathrm{ml}$, plasma calcium $8.0 \mathrm{mg} / 100 \mathrm{ml}$, inorganic phosphorous $1.3 \mathrm{mg} / 100 \mathrm{ml}$, alkaline phosphatase $38 \mathrm{KA}$ units, and total serum protein $6 \cdot 8 \mathrm{~g} / 100 \mathrm{ml}$. Serum transaminases were normal. Urine volumes varied between 5-6 1 daily, and contained 100-200 g glucose, and about $90 \mathrm{mEq}$ sodium and $45 \mathrm{mEq}$ potassium. There was a generalized amino-aciduria. Chest $x$-ray was normal, the bones were somewhat porotic and bone age was 5 years. Barium meal showed widening of the jejunum with coarse mucosal folds. Faecal fat was $4.5 \mathrm{~g}$ /day (mean of 5 days). Results of special investigations are given separately.

The electrolyte abnormality was treated with sodium bicarbonate and potassium supplements, and serum values gradually returned to normal, as did plasma calcium and inorganic phosphorus; the aminoaciduria improved. Insulin, both beef and pork, was given in doses up to a total of 1000 IU daily without apparent effect and the subsequent addition of metformin 1.5 g/day was also without effect. Trials of fructose and xylitol as alternative dietary carbohydrate were without benefit. She was discharged on electrolyte and alkali supplements only. Subsequent progress was complicated by episodes of infection, including otitis media, dental abscess, pneumonia, and ischiorectal abscess. At the age of 7.8 years she died at home after a short diarrhoeal illness.

Post-mortem examination showed distension of the whole of the small intestine, and of the ascending colon. There was a small amount of peritoneal fluid. The liver was slightly enlarged. Spleen, pancreas, adrenals, and kidneys appeared normal. The ovaries were enlarged and somewhat cystic, but the uterus and adnexa were normal. The appearance of the brain was normal and the pituitary gland was of normal size. The pineal gland was grossly enlarged, weighing $900 \mathrm{mg}$ (normal $<150 \mathrm{mg}$ ). On microscopical examination, the pancreas showed conspicuous hyalinization of the islets. The adrenals showed well-marked compact cell change. The ovaries were histologically normal, as were sections of myocardium, skeletal muscle, brain, stomach, jejunum, caecum, spleen, thyroid, and uterus. The lungs showed alveolar congestion, and in the liver there was some vacuolation of the parenchymal cells and dilatation of the sinusoids. There was hyalinization of some of the afferent arterioles of the kidney. The pituitary was normal in size, with normal proportions of the various cell types. The pineal, though enlarged, showed no histological abnormalities (Fig. 2).

Case 2. A boy, the brother of Case 1, was born at term weighing $2 \cdot 3 \mathrm{~kg}$. His facial appearance was similar to his sister's; primary dentition started at 4 months and secondary dentition at 3 years. Roughness of the skin was noted at the age of 9 months and thickened nails at 1.5 years. In view of the similarity to his sister he was investigated at The Hospital for Sick Children at the age of $3 \cdot 1$ years.

On examination the facial resemblance to his sister was obvious (Fig. 3). He was, however, well nourished, with both height and weight between the 3rd and 10th centiles. His skin was dry, moderately hirsute, and with acanthosis nigricans of neck, axillae, and cubital fossae. The nails were thickened, the teeth were dysplastic and carious, and the dental age advanced. The tongue was fissured, the abdomen was somewhat protuberant, and there was penile enlargement but no pubic hair or testicular enlargement. Urine analysis showed occasional glycosuria, but there was no polyuria or polydypsia, and hyperglycaemia could not be shown. Results of special investigations are given later.

When reviewed at the age of 4.9 years his clinical condition was essentially unchanged. By $6 \cdot 8$ years, however, he had developed increased thirst and polyuria though he remained well nourished. His dental age was around 14 years. Urine volume varied between 3-4 1 daily, and contained approximately $200 \mathrm{~g}$ glucose/24 h. Fasting blood glucose varied between 200 and 260 $\mathrm{mg} / 100 \mathrm{ml}$. He was ketonuric and mildly hypokalaemic, but was not acidotic. Hypokalaemia was corrected by oral potassium supplements but neither insulin nor oral hypoglycaemic drugs have been used.

At the time of writing he was 7.5 years old; there has been no major clinical progression of his disease. 


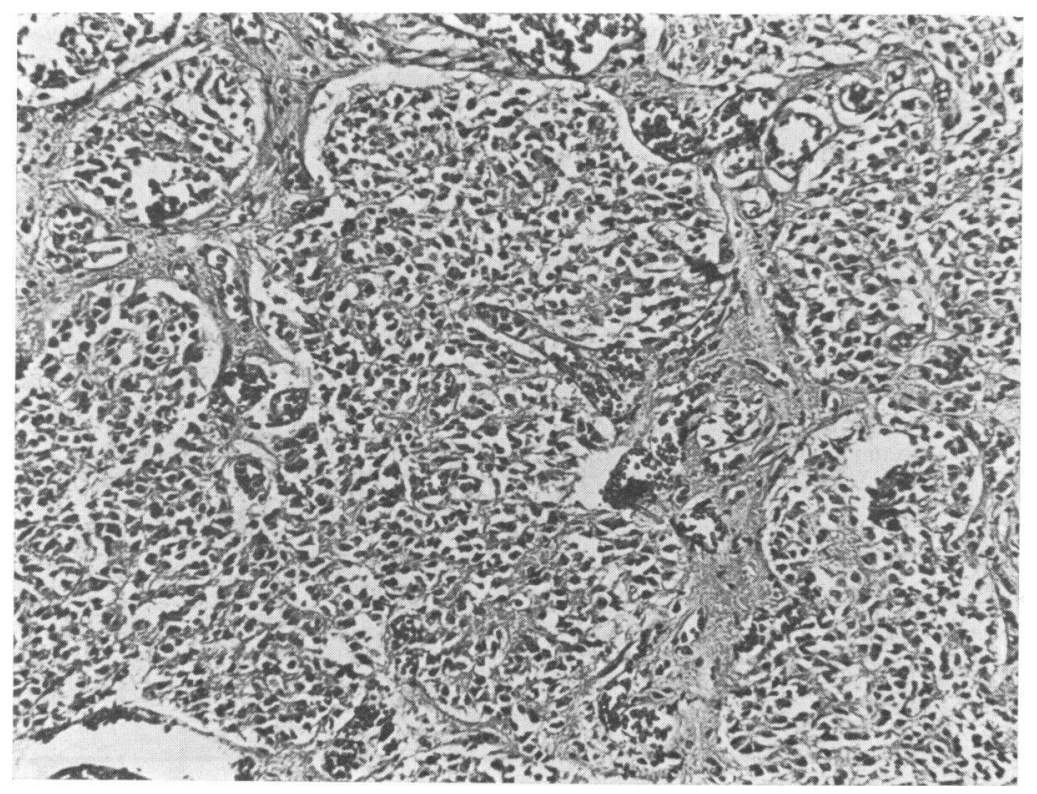

Fig. 2.-Case 1. Microscopy of the pineal gland.

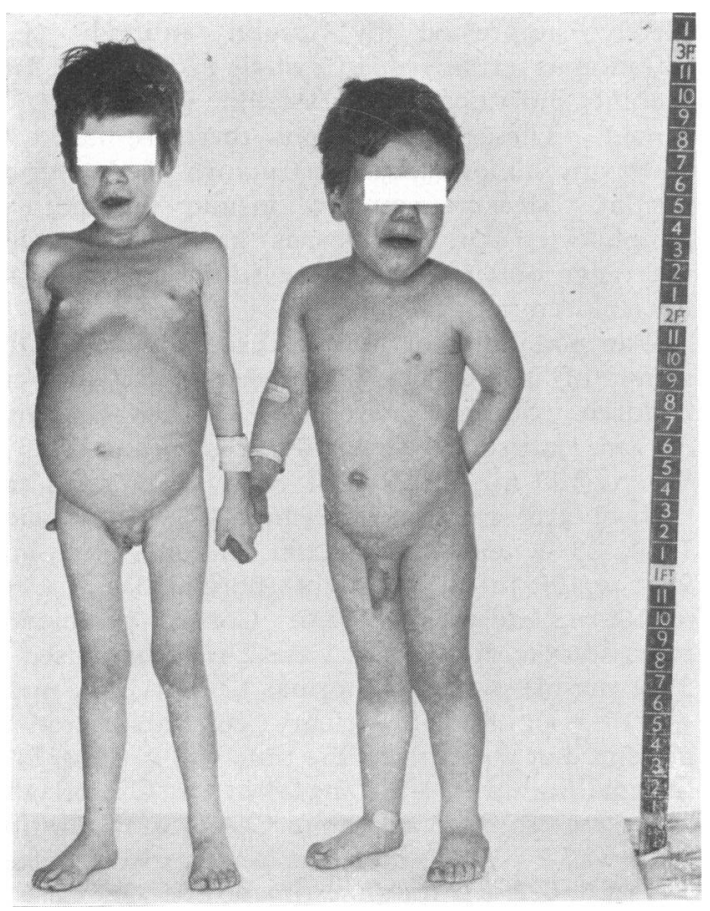

Fig. 3.-Cases 1 and 2. Two sibs showing facial resemblance, abdominal protrusion, and phallic enlargement in both girl and boy.

\section{Special investigations}

Glucose tolerance tests. Glucose tolerance tests (GTT), using oral glucose $(1 \cdot 75 \mathrm{~g} / \mathrm{kg}$ body weight to a maximum of $50 \mathrm{~g}$ ) and measuring blood glucose and serum insulin at $0,30,60,90,120$, and 150 minutes, were performed on both children and their parents; plasma nonesterified fatty acids (NEFA) were measured in most tests. Glucose was measured on venous blood by an autoanalyser glucose oxidase method, serum insulin by a double binding radioimmunoassay, and plasma NEFA by the method of Fosbrooke and Tamir (1968). In Case 1 the test was done at the age of $7 \cdot 3$ years, 2 months after discontinuing insulin therapy. In Case 2 , tests were performed at $3 \cdot 1,4 \cdot 9$, and $6 \cdot 8$ years.

Measurement of serum insulin in Case 1 was complicated by the presence of antibody, presumably induced by exogenous insulin. Fractionation of two of the serum samples through a G100 Sephadex column removed the antibody and enabled an approximate result to be obtained. In Case 2 antibodies were not present in the serum. The results of the GTTs are shown in the Table. In Case 1 there was marked hyperglycaemia throughout the test, and serum insulin at 0 and 60 minutes was high; the response of plasma NEFA was normal. In Case 2 the first GTT showed normal glucose tolerance, but extremely high serum insulin con- 
TABLE

Results of oral glucose tolerance tests in patients and parents

\begin{tabular}{|c|c|c|c|c|c|c|c|c|}
\hline \multirow{2}{*}{ Subject } & \multirow{2}{*}{$\begin{array}{l}\text { Age } \\
(y \mathbf{r})\end{array}$} & \multirow{2}{*}{ Estimation } & \multicolumn{6}{|c|}{ Minutes after glucose } \\
\hline & & & $\mathbf{0}$ & 30 & 60 & 90 & 120 & 150 \\
\hline \multirow[t]{2}{*}{ Case 1} & $7 \cdot 3$ & $\begin{array}{l}\text { Glucose }(\mathrm{mg} / 100 \mathrm{ml}) \\
\text { Insulin }(\mu \mathrm{U} / \mathrm{ml})^{\star} \\
\text { NEFA }(\mathrm{mEq} / \mathrm{l})\end{array}$ & $\begin{array}{l}265 \\
212 \\
1 \cdot 56\end{array}$ & $\begin{array}{l}387 \\
\overline{0} \cdot 70\end{array}$ & $\begin{array}{l}370 \\
440 \\
0 \cdot 84\end{array}$ & $\begin{array}{l}310 \\
\overline{0} \cdot 72\end{array}$ & $\begin{array}{l}286 \\
\overline{0} \cdot 62\end{array}$ & $\begin{array}{l}246 \\
\frac{-}{1 \cdot 77}\end{array}$ \\
\hline & $\int 3 \cdot 1$ & $\begin{array}{l}\text { Glucose }(\mathrm{mg} / 100 \mathrm{ml}) \\
\text { Insulin }(\mu \mathrm{U} / \mathrm{ml}) \\
\text { NEFA }(\mathrm{mEq} / \mathrm{l})\end{array}$ & $\begin{array}{r}42 \\
556 \\
1 \cdot 98\end{array}$ & $\begin{array}{r}154 \\
3208 \\
1 \cdot 93\end{array}$ & $\begin{array}{r}144 \\
3136 \\
0.53\end{array}$ & $\begin{array}{r}122 \\
2875 \\
0 \cdot 44\end{array}$ & $\begin{array}{r}109 \\
3187 \\
0.58\end{array}$ & $\begin{array}{r}84 \\
2656 \\
0 \cdot 88\end{array}$ \\
\hline \multirow[t]{2}{*}{ Case 2} & $4 \cdot 9$ & $\begin{array}{l}\text { Glucose }(\mathrm{mg} / 100 \mathrm{ml}) \\
\text { Insulin }(\mu \mathrm{U} / \mathrm{ml}) \\
\text { NEFA }(\mathrm{mEq} / \mathrm{l})\end{array}$ & $\begin{array}{r}90 \\
1050 \\
0 \cdot 88\end{array}$ & $\begin{array}{l}232 \\
4050 \\
0.50\end{array}$ & $\begin{array}{c}250 \\
3125 \\
-\end{array}$ & $\begin{array}{r}231 \\
4300 \\
0 \cdot 29\end{array}$ & $\begin{array}{l}174 \\
3350 \\
0 \cdot 26\end{array}$ & $\begin{array}{r}104 \\
1600 \\
0 \cdot 47\end{array}$ \\
\hline & $6 \cdot 8$ & $\begin{array}{l}\text { Glucose }(\mathrm{mg} / 100 \mathrm{ml}) \\
\text { Insulin }(\mu \mathrm{U} / \mathrm{ml})\end{array}$ & $\begin{array}{l}259 \\
498\end{array}$ & $\begin{array}{l}460 \\
535\end{array}$ & $7^{469}$ & $\begin{array}{l}362 \\
909\end{array}$ & $\begin{array}{l}218 \\
393\end{array}$ & $\begin{array}{l}252 \\
288\end{array}$ \\
\hline Father & 32 & $\begin{array}{l}\text { Glucose }(\mathrm{mg} / 100 \mathrm{ml}) \\
\text { Insulin }(\mu \mathrm{U} / \mathrm{ml}) \\
\text { NEFA }(\mathrm{mEq} / \mathrm{l})\end{array}$ & $\begin{array}{l}78 \\
16 \\
0.45\end{array}$ & $\begin{array}{l}128 \\
130 \\
0 \cdot 19\end{array}$ & $\begin{array}{l}103 \\
136 \\
0 \cdot 17\end{array}$ & $\begin{array}{l}34 \\
23 \\
0 \cdot 26\end{array}$ & $\begin{array}{l}55 \\
8 \\
0 \cdot 47\end{array}$ & $\begin{array}{l}74 \\
11 \\
0 \cdot 71\end{array}$ \\
\hline
\end{tabular}

^After removal of circulating antibody.

NEFA, plasma nonesterified fatty acids.

centrations. The second and third tests showed progressively impaired glucose tolerance; in the third test serum insulin values were still markedly raised though somewhat lower than previously. Plasma NEFA response was normal in the two tests where it was measured.

The mother had normal glucose tolerance but somewhat raised serum insulin values throughout the test. The interpretation of these results is hampered by the fact that she was at the time taking Ovulen 50 (Searle) for contraceptive purposes; it seems unlikely, however, that this drug was the sole cause of the hyperinsulinaemia (Wynn and Doar, 1969). The father had a normal response to oral glucose for all 3 variables measured (Table).

Investigation of insulin resistance. Investigation of Case 1 was hampered by the presence of antibodies and the very poor clinical condition with evidence of many secondary metabolic abnormalities. Most investigations have therefore been carried out on Case 2 who never received exogenous insulin and whose general clinical state was good at the time of testing. Measurement of his serum insulin by radioimmunoassay has always shown grossly raised values, and no antibody or proinsulin has been detected on any occasion. Bioassay of serum insulin, using isolated fat cells (Dr. O. Sovik) gave a value of $5133 \mu \mathrm{U} / \mathrm{ml}$, compared with immunoreactive serum insulin of $5850 \mu \mathrm{U} / \mathrm{ml}$ on the same sample. Insulin activity in this sample was completely suppressed by insulin antibody. Gel filtration of serum yielded a single insulin peak with mobility indentical with crystalline insulin (Dr. O. Sovik). These investigations therefore failed to show any abnormality of structure of the serum insulin. Measurement of insulin binding of lymphocytes (Dr. N. Lazarus) gave values within the range obtained for obese adults (normal data for children not available).

The possibility of hormonal antagonism to the action of insulin has been investigated in both children. Serum cortisol in Case 1 was normal (9 a.m. cortisol $14 \cdot 0 \mu \mathrm{g} / 100 \mathrm{ml}$; normal $17 \cdot 3 \pm$ $7.8 \mu \mathrm{g} / 100 \mathrm{ml}$, mean $\pm 1 \mathrm{SD}$ ). In Case 2 the cortisol level was sometimes high, the values being $13 \cdot 4,28 \cdot 0$, and $28 \cdot 5 \mu \mathrm{g} / 100 \mathrm{ml}$ for 9 a.m., and $9.6 \mu \mathrm{g} / 100 \mathrm{ml}$ at midnight (normal $3.1 \pm 1 \cdot 2$ $\mu \mathrm{g} / 100 \mathrm{ml}$, mean $\pm 1 \mathrm{SD}$ ). Cortisol production rate (isotopic dilution) in Case 2 was also raised at $23 \cdot 2 \mathrm{mg} / \mathrm{m}^{2}$ per $24 \mathrm{~h}$ (normal $12 \cdot 3 \pm 2 \cdot 8$, mean $\pm 1 \mathrm{SD}$ ), though urinary cortisol excretion, measured at about the same time was $0.8 \mathrm{mg} / 24 \mathrm{~h}$ (normal for age $0 \cdot 4-3 \cdot 2 \mathrm{mg} / 24 \mathrm{~h}, \mathrm{Dr}$. C. Forsyth).

Plasma growth hormone in Case 1 in the fasting state was $7 \mu \mathrm{U} / \mathrm{ml}$, and in Case 2 varied between 3.3 and $6 \cdot 2 \mu \mathrm{U} / \mathrm{ml}$ ( 3 estimations). In Case 2 the response to oral Bovril (Jackson, Grant, and Clayton, 1968) was subnormal with a maximum value of $8 \cdot 2 \mu \mathrm{U} / \mathrm{ml}$ (normal rise of at least $7 \mu \mathrm{U} / \mathrm{ml}$ ); 
however, on one occasion during a GTT a growth hormone level of $>40 \mu \mathrm{U} / \mathrm{ml}$ was recorded.

Plasma glucagon (Dr. S. Bloom) in Case 2 at a time when he was hyperglycaemic (blood glucose $300 \mathrm{mg} / 100 \mathrm{ml}$ ) was $97 \mathrm{pg} / \mathrm{ml}$ (normal adults 10-59 $\mathrm{pg} / \mathrm{ml}$ ). No direct estimations of catecholamines were made; urinary VMA in Case 2 was 1.9 $\mathrm{mg} / 24 \mathrm{~h}$ (normal up to $3 \cdot 3 \mathrm{mg} / 24 \mathrm{~h}$ ).

Other endocrine investigations. In Case 1 protein-bound iodine was $5 \mu \mathrm{g} / 100 \mathrm{ml}$ (normal 2.5$6.6 \mu \mathrm{g} / 100 \mathrm{ml}$ ). Urinary ketosteroid excretion was $2.6 \mathrm{mg} / 24 \mathrm{~h}$, and hydroxycorticoid excretion was $7.4 \mathrm{mg} / 24 \mathrm{~h}$ (both mean of 3 ; normal ketosteroids $1 \cdot 4 \pm 0 \cdot 7$, mean $\pm \mathrm{ISD}$, hydroxycorticoids $0 \cdot 6-$ $6.4 \mathrm{mg} / 24 \mathrm{~h}$ ).

In Case 2 it was possible to assay a number of pituitary hormones in addition to growth hormone; normal results were obtained for serum thyroid stimulating hormone $(1 \cdot 8 \mu \mathrm{U} / \mathrm{ml}$, Dr. B. Ormston), ACTH $(9$ a.m. $33 \mathrm{pg} / \mathrm{ml}$, midnight $<12 \mathrm{pg} / \mathrm{ml}$, Dr. L. Rees), FSH ( $<16$ pg/ml, Dr. L. Rees), and prolactin $(11 \cdot 2 \mathrm{ng} / \mathrm{ml})$. Urinary leutinizing hormone was raised at $9.5 \mathrm{IU} / 24 \mathrm{~h}$ (mean of 2 ; normal $1 \cdot 37 \pm 0.45 \mathrm{IU} / 24 \mathrm{~h}$ mean $\pm \mathrm{ISD}$ ); urinary follicle stimulating hormone was $<0.5$ IU (mean of 3; normal $<1 \mathrm{IU} / 24 \mathrm{~h}$ ).

Serum thyroxine was normal $(9.3$ and $6.9 \mu \mathrm{g} /$ $100 \mathrm{ml}$ ), as was plasma testosterone (Dr. B. Rudd). Urinary 17 -ketosteroids at age 4.9 years were 2.9 $\mathrm{mg} / 24 \mathrm{~h}$ (normal for age $0.8 \pm 0.5$, mean \pm $1 \mathrm{SD}$ ), and at age 6.9 were $2.8 \mathrm{mg} / 24 \mathrm{~h}$ (normal for age $1.4 \pm 0.7 \mathrm{mg} / 24 \mathrm{~h}$ ). Urinary dehydroepiandrosterone (Dr. C. Forsyth) was high at $37 \mu \mathrm{g} / 24 \mathrm{~h}$ (normal for age up to $18 \mu \mathrm{g} / 24 \mathrm{~h}$ ), whereas aetiocholanolone, androsterone, 11-deoxy17-ketosteroids, and corticosterone excretions were normal.

Investigation of pineal gland. An attempt to study the pineal gland was made in Case 2. An EMI scan of the brain at the age of 7 years showed a normal sized pineal and there was no distortion or enlargement of the ventricular system. Urinary 5-hydroxy-indole-acetic acid (formed during melatonin synthesis) excretion was not raised (Dr. $\mathrm{K}$. Blau). Administration of oral melatonin in dosage up to $200 \mathrm{mg}$ /day for 12 days did not improve the diabetic state (Fig. 4), though the recognized side effects of drowsiness and slurring of speech occurred.

\section{Discussion}

Our patients most closely resemble the family reported by Rabson and Mendenhall (1956) and

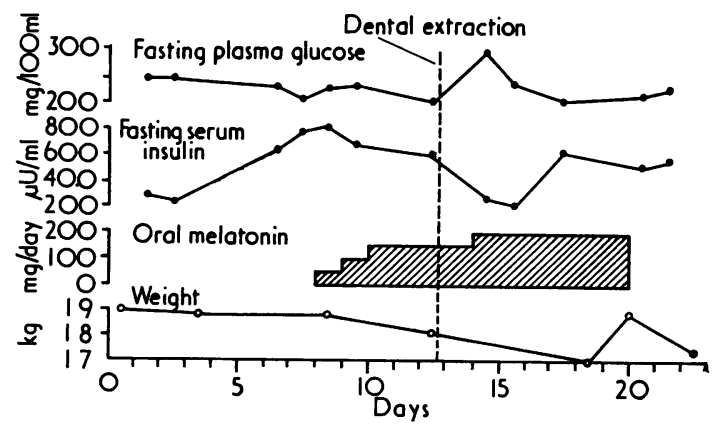

FIG. 4.-Case 2. Effect of melatonin on fasting plasma glucose, serum insulin, and body weight.

the patient of Mason and Sly (1937). From these 6 patients the characteristic features of the syndrome appear to be low birthweight, dry skin, thickened nails, hirsutism, acanthosis nigricans, dental precocity and dysplasia, abdominal protuberance, phallic enlargement, and insulin-resistant diabetes mellitus with ketosis developing during childhood, and association with frequent septic episodes. All 3 children described by Rabson and Mendenhall (1956) and Case 1 of our family died in midchildhood, necropsy showing marked pineal hyperplasia. No follow-up of the patient of Mason and Sly (1937 is available after the age of 2 years.

The brother and sister described by Wiedemann et al. (1968) did not have abdominal distension or phallic enlargement, and were still living at the ages of 13 and 11, respectively; the 2 sisters described by Barnes et al. (1974) did not have abnormal teeth or nails, and are surviving at the ages of 23 and 11 years. However, as both these sibships have many similarities to the other 6 patients, they may represent less severe variants of the syndrome. The syndrome appears to show autosomal recessive inheritance, and the 2 sisters described by Barnes et al. (1974) were daughters of a first-cousin marriage. The raised serum insulin found in the mother of our patients may be a biochemical indication of her heterozygous status.

The mechanism of the insulin resistance has not yet been established. Insulin antibodies were not present in Case 2, or intially in Case 1. Growth hormone, cortisol, glucagon, and adrenalin were not present in amounts likely to cause insulin resistance. Suppression of plasma NEFA by oral glucose in both our patients suggested that adipose tissue at least was not totally resistant to the action of insulin. Nevertheless, some form of tissue resistance cannot be completely excluded.

The role of the pineal gland in this syndrome can 
only be speculative. In man the only pineal hormone definitely identified is melatonin ( $n$ acetyl-methoxy-tryptamine), which is known to suppress gonadal development by acting on the hypothalamus to inhibit the liberation of gonadotrophic-releasing factors (Kappers, 1971). Rabson and Mendenhall (1956) suggested that the pineal hyperplasia in their patients might be associated with defective production of pineal hormones, in a manner analogous to the situation in congenital adrenal hyperplasia. This could explain the phallic enlargement, but for such a mechanism to explain insulin resistance as well it would be necessary to postulate either that pineal deficiency itself induced insulin resistance or that there was excessive production of another pineal hormone which was antagonistic to insulin. Destruction of the pineal gland by tumour has induced sexual precocity (Pelizzi, 1910) but insulin resistance has never been reported. The failure of exogenous melatonin to influence either blood glucose or serum insulin in Case 2 makes it unlikely that pineal hypofunction, at least in respect of melatonin production, can be the cause of this syndrome.

The phallic enlargement, present in all 6 typical patients, suggests the action of an androgen, and if excessive production of such a hormone is not due to failure of pineal inhibition, the primary abnormality may be in either the hypothalamus or the anterior pituitary, or the adrenal. There is no evidence to support a primary adrenal abnormality. However, a primary abnormality in the hypothalamus or pituitary is a possibility. Louis and Conn (1972) have described a diabetogenic polypeptide which they have isolated from human pituitaries which is distinct from previously recognized pituitary hormones and, if there was disturbance of function of hypothalamus or pituitary, production of such a hormone could explain the diabetes and insulin resistance; excess FSH production could lead indirectly to the phallic enlargement, and pineal hyperplasia might be explained by feedback mechanisms attempting to inhibit this FSH. The failure to show pineal hyperplasia in our second patient may be due to the limitations of EMI scanning, or may simply reflect the stage of his disease. Serial studies are clearly indicated.

A unifying hypothesis to explain all the somatic and metabolic features in this syndrome is not yet possible. The extremely high circulating insulin concentrations present from an early age may possibly play some part in the development of the dental, skin, and nail abnormalities.

We thank Dr. Helen Blyth for drawing our attention to the report by Rabson and Mendenhall; Mrs. Doreen Jackson and the other staff of the Department of Chemical Pathology, The Hospital for Sick Children, for many endocrine estimations; all those mentioned in the text for special investigations; and the many clinical colleagues with whom we had helpful discussion.

\section{REFERENCES}

Barnes, N. D., Palumbo, P. J., Hayles, A. B., and Folgar, H. (1974) Insulin resistance, skin changes and virilization; a recessively inherited syndrome possibly due to pineal gland dysfunction. Diabetalogia, 10, 285.

Fosbrooke, A. S., and Tamir, I. (1968). A modified method for the preparation of methyl esters of a mixture of medium-chain and long-chain fatty acids. Clinica Chimica Acta, 20, 517.

Jackson, D., Grant, D. B., and Clayton, B. B. (1968). A simple oral test of growth-hormone secretion in children. Lancet, 2, 373.

Kappers, J. A. (1971). The pineal organ. The Pineal Gland, p. 3. Ed. by G. E. W. Wolstenholme and J. Knight. Churchill Livingstone, Edinburgh and London.

Louis, L. H., and Conn, J. W. (1972). Diabetogenic polypeptide from human pituitaries similar to that excreted by proteinuric diabetic patients. Metabolism, 21, 1 .

Mason, H. H., and Sly, G. B. (1937). Diabetes mellitus : report of a case resistant to insulin but responsive to a change in the type of carbohydrate fed. Fournal of the American Medical Association, 108, 2016.

Pelizzi, G. B. (1910). La sindrome epifisaria 'macrogenitosomia precoce'. Rivista Italiana Neuropatologia, 3, 193.

Rabson, S. M., and Mendenhall, E. N. (1956). Familial hypertrophy of pineal body, hyperplasia of adrenal cortex and diabetes mellitus. American fournal of Clinical Pathology, 26, 283.

Wiedemann, H. R., Spranger, J., Mogharei, M., Kübler, W., Tolksdorf, M., Bontemps, M., Drescher, J., and Gunschera, H. (1968). Úber das syndrom Exomphalos-Makroglossie-Gigantismus, über generalisiekite Muskelhypertrophie, progressive Lipodystrophie und Miescher-syndrom im sinne diencephaler syndrome. Zeitschrift fikr Kinderheikunde, 102, 1.

Wynn, V., and Doar, J. W. H. (1969). Some effects of oral contraceptives on carbohydrate metabolism. Lancet, $2,761$.

Correspondence to Dr. R. J. West, Department of Child Health, St. Georges Hospital, Blackshaw Road, Tooting, London SW17. 